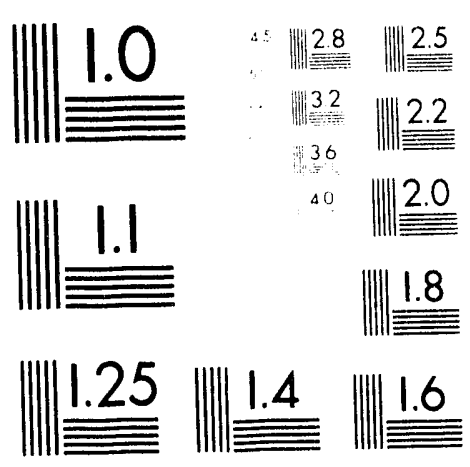



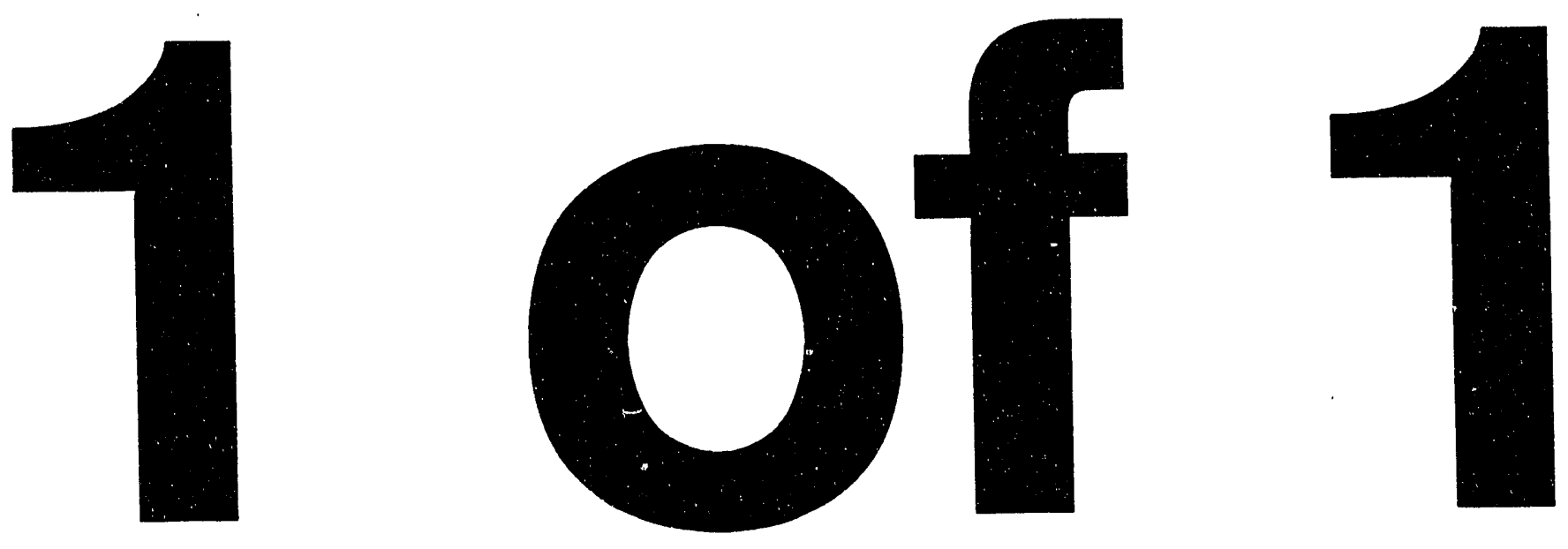
Distribution Category:

Chemistry

UC-401

ANL-93/24

Argonne National Laboratory

9700 South Cass Avenue

Argonne, Illinois 60439

ANNUAL REPORT FOR ION REPLACEMENT PROGRAM

by

Z. Tomczuk, J. L. Willit, and A. K. Fischer

Ion Replacement Program

Chemical Technology Division

July 1993 


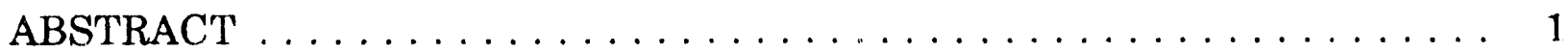

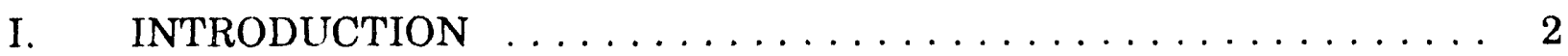

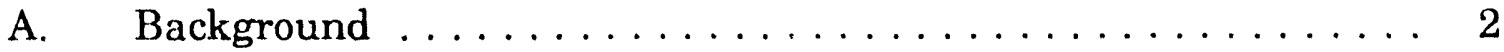

B. Approach $\ldots \ldots \ldots \ldots \ldots \ldots \ldots \ldots \ldots \ldots \ldots \ldots$

II. EXPERIMENTAL $\ldots \ldots \ldots \ldots \ldots \ldots \ldots \ldots \ldots \ldots \ldots \ldots \ldots \ldots \ldots \ldots$

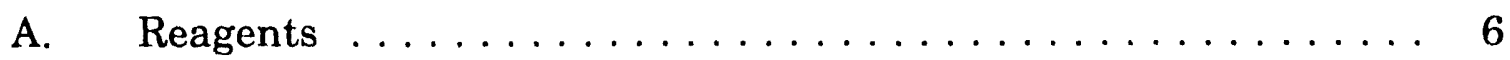

B. Equipment ..................... 7

C. Experimental Procedures $\ldots \ldots \ldots \ldots \ldots \ldots \ldots \ldots$

III. RESULTS AND DISCUSSION $\ldots \ldots \ldots \ldots \ldots \ldots \ldots \ldots \ldots$

A. Rare Earth Studies $\ldots \ldots \ldots \ldots \ldots \ldots \ldots \ldots$

B. Uranium Studies $\ldots \ldots \ldots \ldots \ldots \ldots \ldots \ldots \ldots \ldots$

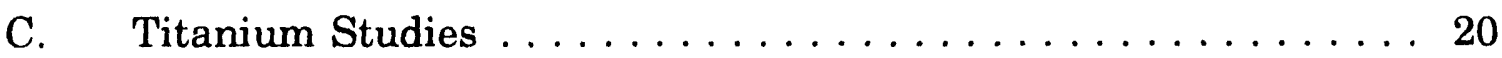

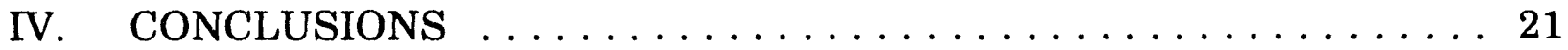

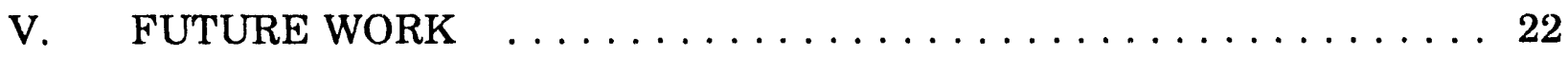

VI. ACKNOWLEDGMENTS $\ldots \ldots \ldots \ldots \ldots \ldots \ldots \ldots \ldots \ldots \ldots 22$

VII. REFERENCES ........................ 23 


\section{LIST OF FIGURES}

No.

$\underline{\text { Page }}$

1. Diagram of Anodic Dissolution Step in Ion Replacement $\ldots \ldots \ldots 2$

2. Diagram of Cathodic Deposition Step in Ion Replacement $\ldots \ldots \ldots .3$

3. Diagram of Glovebox Furnace Well and Electrochemical Cell

Used in all Experiments Described in this Report . . . . . . . . . . 7

4. Glovebox Facility Used for all Non-Uranium Experiments . . . . . . 8

5. Stainless Steel Shroud Assembly Used to Support $\beta$ "-Alumina Tube . . 8

6. Top View of Heat Shields for Ion Replacement Cell as Seen

through the Glovebox Window .................... 9

7. Current (i), Potential (E), and Charge (Q) vs. Time for

Experiment IRP-1 ..................... 11

8. Cathode Deposit from Experiment IRP-1 $\ldots \ldots \ldots \ldots \ldots \ldots \ldots \ldots$

9. Plot of Concentration vs. Potential for $\mathrm{DyCl}_{3}, \mathrm{DyCl}_{2}, \mathrm{Dy}$,

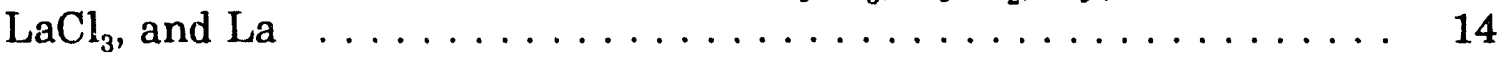

10. Current, Potential, and Charge vs. Time Data from Experiments

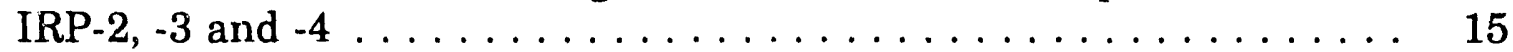

11. Current, Potential, and Charge vs. Time Data from Experiment

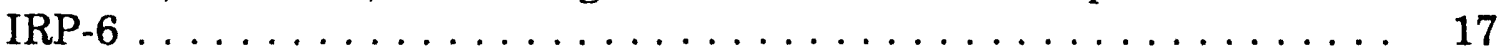

12. Uranium Rod after Experiment IRP-11 . . . . . . . . . . 19 


\section{LIST OF TABLES}

No.

Page

1. Calculated Maximum Theoretical Product Purity as Function of $\Delta \mathrm{E}_{\text {dep }}$ for Three-Electron Reduction Reactions . . . . . . . . . . 4

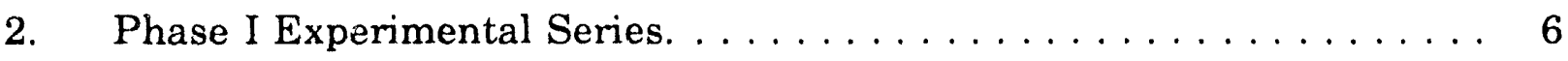

3. Analysis Results for Cathode Deposit from IRP $-1 \ldots \ldots \ldots \ldots \ldots$

4. Initial and Final Concentration, Percent Change, and Change in Equivalents of Dy, La, and $\mathrm{Na}$ from Experiment IRP-1 . . . . . . . 13

5. Initial and Final Concentration, Percent Change, and Equivalents Charged or Discharged of Dy, La, and $\mathrm{Na}$ in Experiment IRP-2 . . . . 15

6. Initial and Final Concentration, Percent Change, and Equivalents Charged or Discharged of Dy, La, and $\mathrm{Na}$ in Experiment IRP-4 . . . . 16 


\title{
ANNUAL REPORT FOR ION REPIACEMENT PROGRAM
}

by

\author{
Z. Tomczuk, J. L. Willit, \\ and A. K. Fischer
}

\begin{abstract}
Ion replacement electrorefining is an innovative electrochemical approach to purifying and separating metals. This approach overcomes the shortcomings of conventional electrorefining and has the potential for processing a wider range of metals and metal halide salts. Salt waste is also minimized with this approach. The key element of ion replacement electrorefining is the ion replacement electrode. This electrode allows a decoupling of the electrotransport process into two separate steps, anodic dissolution and cathodic deposition.

This report summarizes the activities from February 1992 through May 1993 in the Ion Replacement Electrorefining Program at Argonne National Laboratory. Three key accomplishments described in this report that demonstrate the feasibility of ion replacement electrorefining are: (1) we have identified a suitable sodium/ $\beta$ "-alumina/molten salt electrolyte system that functions reproducibly at $723 \mathrm{~K}$, (2) we have oxidized and deposited dysprosium, lanthanum, uranium, and titanium by using a sodium ion replacement electrode. In several experiments, an actual separation of dysprosium and lanthanum was observed, and (3) we have identified a metal alloy, $\mathrm{Li}_{x} \mathrm{Sb}$, as an alternative ion replacement electrode. The next stage in the program is the design, construction, and testing of a laboratory-scale electrorefiner. Follow-on development with funding from industrial and federal sponsors is being pursued.
\end{abstract}




\section{INTRODUCTION}

\section{A. Background}

Ion replacement electrorefining is an innovative electrochemical approach to separating and purifying metals. This approach has several key distinctions from the two dominant electrochemical processes presently used to separate and purify metals, namely, conventional electrorefining and electrowinning. Both electrowinning and conventional electrorefining are one-step, electrolytic processes. In conventional electrorefining, pure metal is electrotransported from an impure metal anode to a cathode. The less noble impurities remain in the electrolyte, and the more noble impurities remain in the anode. This process is well established and has been used for years in purification of actinides. ${ }^{1}$

Whereas conventional electrorefining is used for purification of metals, electrowinning is used for recovering oxidized metals from an electrolyte. During electrolysis of an electrolyte containing one or more oxidized metals, the most noble metal deposits at the cathode. At the anode, the most easily oxidized species in the electrolyte or in the anode is oxidized. Aluminum is probably the most familiar metal that is commercially produced by electrowinning. Typical anode products in the electrowinning of aluminum are chlorine, carbon dioxide, and oxygen. Over the years, the major challenge in most electrowinning processes has been the development of stable electrodes that over time do not react or disintegrate.

Ion replacement electrorefining is a two-step process (anodic dissolution and cathodic deposition) that can handle both metallic or oxidized feed material. Processing metallic feed is accomplished by the two-step process, whereas only the second step is needed for processing oxidized feed. The first step in ion replacement electrorefining is shown in Fig. 1. At the anocie, the metal feed is oxidized into the electrolyte. At the ion replacement electrode, alkali or alkaline earth cations are reduced to the metallic state. An ion-conducting solid electrolyte separates the reduced alkali or alkaline earth metal

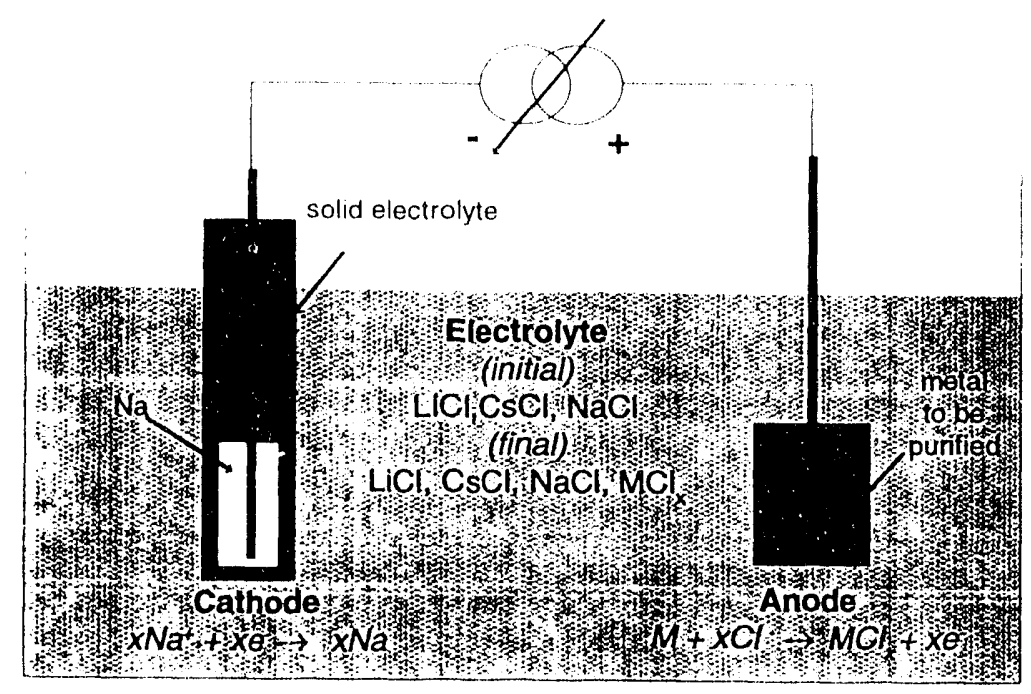

Fig. 1. Diagram of Anodic Dissolution Step in Ion Replacement 
from the electrolyte. This step is not spontaneous. The second step in ion replacement electrorefining is shown in Fig. 2. The cell polarity is reversed from that shown in Fig. 1. At the ion replacement electrode, alkali or alkaline earth metal is oxidized. The second step is spontaneous and is analogous to discharging a battery. At the cathode, metal cations are reduced sequentially in order of increasing free energy of formation of the oxidized species.

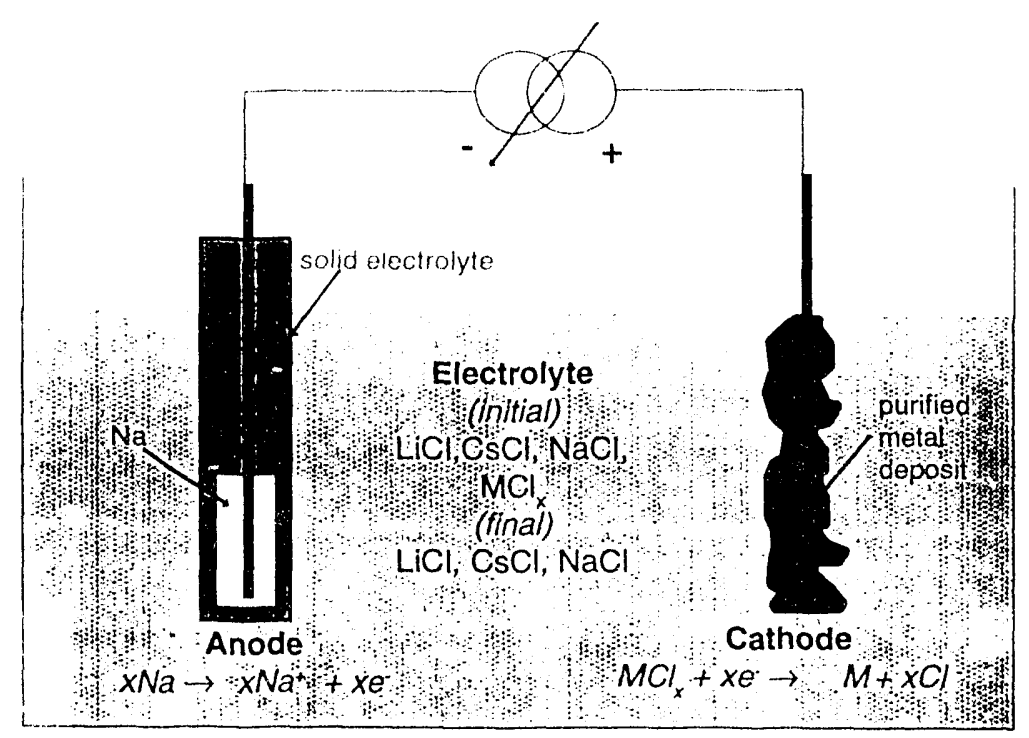

Fig. 2. Diagram of Cathodic Deposition Step in Ion Replacement

We refer to our approach as "ion replacement electrorefining" because in the first step the alkali or alkaline earth cations reduced at the ion replacement electrode are replaced by metal cations formed at the anode. In the second step, the metal cations reduced at the cathode are replaced by alkali or alkaline earth cations formed at the ion replacement electrode.

Ion replacement electrorefining offers several advantages over conventional electrorefining and electrowinning. First, ion replacement can handle both metallic and oxidized feed material. Conventional electrorefining and electrowinning can handle only a single type of feed material. Second, ion replacement electrorefining virtually eliminates the electrolyte waste encountered in conventional electrorefining. In conventional electrorefining, the electrolyte must be periodically discarded as waste due to the buildup of impurities. Waste volume from conventional electrorefining processes can be reduced by treating the salt via some other process to remove the impurities and/or recover the oxidized metal remaining in the electrolyte. However, this requires a separate process and separate equipment, and still results in some type of waste stream. Ion replacement can be used to recover all the oxidized metal and the impurities from the electrolyte and return the electrolyte to its initial composition, thereby eliminating the electrolyte waste stream. Third, formation of corrosive anode products or disintegration of electrodes as occurs in most electrowinning processes, does not occur in ion replacement electrorefining. 
In most cases, very pure deposits can be obtained from multi-metal feed material. The key determining factor in the separation of two metals is the difference in their deposition potential, $\Delta \mathrm{E}_{\mathrm{dup}}$. 'Table 1 shows the maximum theoretical purity of product that can be obtained as a function of $\Delta \mathrm{E}_{\mathrm{dep}}$. For simplicity, in the calculation, we assumed a three-electron reduction reaction with a value of 1 for all activity coefficients.

Table 1. Calculated Maximum Theoretical Product Purity as Function of $\Delta \mathrm{E}_{\mathrm{dep}}$ for Three-Electron Reduction Reactions. Temperature $=728 \mathrm{~K}$ and all activity coefficients $=1$.

\begin{tabular}{|c|c|}
\hline $\begin{array}{c}\Delta \mathbf{E}_{\text {dep }} \\
(\mathbf{V})\end{array}$ & $\begin{array}{c}\text { Maximum Theoretical Product Purity } \\
\text { (atom \%) }\end{array}$ \\
\hline 0.001 & 51.195 \\
\hline 0.010 & 61.733 \\
\hline 0.100 & 99.169 \\
\hline 0.200 & 99.993 \\
\hline 0.300 & 99.9999 \\
\hline
\end{tabular}

Operation of an ion replacement cell is quite similar to that of other electrochemical processes. Like most large-scale electrochemical processes, ion replacement electrorefining can be performed in controlled-current or controlled-potential modes but is typically operated in the controlled-current mode. In this mode of operation, the cell voltage indicates the species being deposited. A series of cathodes can be used to collect the different fractions of metals deposited from the electrolyte. More specialized techniques developed for conventional electrorefining processes can also be used in ion replacement electrorefining. For instance, ion replacement electrorefining can employ liquid metal cathodes to raise or lower the activity of a deposited metal if codeposition of metals is desired or the solubility of a deposited metal needs to be suppressed in the molten salt phase.

This technology has several potential applications in nuclear, non-nuclear, and general science areas. In nuclear areas, ion replacement could be used to recover plutonium and americium from molten salt extraction (MSE) process salt, thus rendering the salt non-transuranic (non-TRU). This technology can also be used in place of expensive chemical oxidants such as $\mathrm{CdCl}_{2}$, which is used to oxidize uranium and plutonium into the electrolyte in a pyroprocess currently being developed. ${ }^{2}$ Valuable metals from spent nuclear fuel may also be recovered with this technology. In the nonnuclear areas, selective separation of transition metals and rare earth metals should be possible. An additional application envisioned is the removal of sodium from molten salt baths used for lithium production. 
The ion replacement approach also has applications in more general scientific areas. For example, much of the work in molten salt electrochemistry requires accurate activity coefficients of species in molten salts. However, for many systems the data base of activity coefficients has been severely lacking and inaccurate. Ion replacement aufords an easy method to prepare dilute solutions containing a large variety of species for determination of accurate activity coefficient data.

\section{B. Approach}

Our initial strategy in this program was to isolate the ion replacement metal from the electrolyte by using an ionic conductor. We selected $\beta^{\prime \prime}$-alumina, a $\mathrm{Na}^{+}$conductor, ${ }^{3}$ from among the many $\mathrm{Na}^{+}$conductors available, such as $\beta$-alumina, ${ }^{3} \mathrm{Na}_{3} \mathrm{Zr}_{2} \mathrm{Si}_{2} \mathrm{PO}_{12}$ (NASICON), ${ }^{4}$ and $\mathrm{Na}_{5} \mathrm{YSi}_{4} \mathrm{O}_{12} \cdot{ }^{4}$ We could also have selected a $\mathrm{Li}^{+}$conductor such as $\mathrm{Li}_{\mathrm{x}} \mathrm{TiS}_{2},{ }^{5} \mathrm{LiI}^{4}$, or $\left.\mathrm{Li}_{3} \mathrm{~N}\right),{ }^{4}$ a $\mathrm{Ag}^{+}$conductor $\left(\mathrm{RbAg}_{4} \mathrm{I}_{5}\right),{ }^{4}$ a $\mathrm{Cu}^{2+}$ conductor $\mathrm{RbCu}_{4} \mathrm{Cl}_{3} \mathrm{I}_{2},{ }^{4}$ or a $\mathrm{F}$. conductor $\left(\beta-\mathrm{PbF}_{2}\right){ }^{4}$ In selecting an ion conductor, our criteria were high ionic conductivity, low electric conductivity, and high decomposition potential. It was also desirable that the material be easily fabricated into a variety of shapes, have high mechanical strength, and not react chemically with molten salts. In addition to satisfying the selection criteria, $\beta$ "-alumina is a well-characterized material and has been often used in molten salt applications, most notably in the $\mathrm{Na} / \mathrm{S}$ battery system.

Most metal chlorides are soluble to a degree in molten chloride salts. Furthermore, molten salt electrolytes afford a much wider electrochemical potential working region than aqueous or organic systems. The selection of $\beta$ "-alumina dictated the molten salt chosen for this work. Many cations will exchange with sodium ions in the $\beta$ "alumina. For example, $\mathrm{Ag}^{+}, \mathrm{K}^{+}$, and $\mathrm{Tl}^{+}$have good exchange with $\mathrm{Na}^{+}$, whereas $\mathrm{Li}^{+}$and $\mathrm{Cs}^{+}$do not exchange appreciably with $\mathrm{Na}^{+}$. The ternary salt $\mathrm{CsCl}-\mathrm{LiCl}-\mathrm{NaCl}$ was selected because its cations do not rapidly exchange with sodium in the $\beta$ "-alumina, and the phase diagram indicates a reasonably large liquid region at $728 \mathrm{~K}^{6}$

The program is structured in two phases. The goals of Phase I are as follows: identify a suitable sodium/ $\beta$ "-alumina/molten salt electrolyte combination capable of operation at 575 to $775 \mathrm{~K},(2)$ conduct tests on the anodic-dissolution and cathodicdeposition behavior of selected materials using sodium electrodes, and (3) identify possible alternatives to the sodium electrode.

Table 2 gives a list of the purpose for each of the Phase I experiments. The designation "IRP" is simply an acronym for ion replacement. These were scoping experiments emphasizing proof-of-concept demonstration of ion replacement electrorefining. Three types of elements were seiected for the proof-of-concept demonstration of ion replacement electrorefining: rare earths, actinides, and group IVA transition metals. 
Tahle 2. Phase 1 Experimental Series

\begin{tabular}{|c|l|}
\hline Experiment \# & Purpose \\
\hline IRP-1 & Co-deposit Iad and Dy \\
\hline IRP-2 & Separate La and Dy \\
\hline IRP-3 & Oxidize deposited Dy \\
\hline IRP-4 & Deposit La and Dy \\
\hline IRP-5 & Recover (via chemical oxidation) dissolved metallic La and Dy \\
\hline IRP-6 & Spontaneously deposit La and Dy \\
\hline IRP-7 & Oxidize and redeposit U \\
\hline IRP-8 & Oxidize Ti \\
\hline IRP-9 & Oxidize U \\
\hline IRP-10 & Deposit Ti \\
\hline IRP-11 & Oxidize U and add DyCl $_{3}$ \\
\hline IRP-12 & Oxidize Ti \\
\hline IRP-13 & Oxidize U and redeposit \\
\hline
\end{tabular}

\section{EXPERIMENTAL}

\section{A. Reagents}

All of the experiments to date have used a $\mathrm{CsCl}(77.7 \mathrm{wt} \%)-\mathrm{LiCl}(13.7 \mathrm{wt} \%)-\mathrm{NaCl}$ (8.6 wt\%) ternary salt. These salts along with $\mathrm{LaCl}_{3}$ and $\mathrm{DyCl}_{3}$ were obtained from APL Engineered Materials (Urbana, IL) and were $>99.99 \%$ pure as analyzed by the manufacturer. Sodium (99.95\% pure) was obtained from Aldrich Chemical Co. (Milwaukee, WI) as ingots sealed under nitrogen in glass ampoules. Uranium and titanium metal rods were obtained from the Special Materials Division at Argonne National Laboratory.

Two sizes of $\beta "$-alumina tubes (closed one end) were obtained from Ceramatec (Salt Lake City, UT) for these experiments. The "small" tubes measured $1.0 \mathrm{~cm} \mathrm{O.D.} \mathrm{x} 10 \mathrm{~cm}$ long $\times 0.09 \mathrm{~cm}$ thick, and the "large" tubes measured $1.5 \mathrm{~cm}$ O.D. $\times 20 \mathrm{~cm}$ long $\times 0.1 \mathrm{~cm}$ thick. $\beta$ "-alumina has a spinel structure and its general formula is $\mathrm{Na}_{1+x} \mathrm{M}_{x} \mathrm{Al}_{11-\mathrm{x}} \mathrm{O}_{17.1}$, where $\mathrm{M}$ is typically $\mathrm{Li}^{+}, \mathrm{Mg}^{2+}, \mathrm{Ni}^{2+}$, or $\mathrm{Zn}^{2+}$. In our case the $\beta^{\prime \prime}$-alumina was doped with $\mathrm{Li}^{+}$. The cation $\mathrm{M}$ substitutes for $\mathrm{Al}^{3+}$ and compensates for the excess positive charge of the conducting $\mathrm{Na}^{+}$ions. ${ }^{7}$ The $\beta^{\prime \prime}$-alumina is a solid electrolyte that has a very high conductivity for sodium ions. Ceramatec reports a sodium ion resistivity of $3.5 \Omega \mathrm{cm}$ at $628 \mathrm{~K}$ for their $\beta$ "-alumina tubes. The sodium ion resistivity decreases with increasing temperature. 


\section{B. Equipment}

Figure 3 is a drawing of the furnace well and electrochemical cell assemb!y that was used to conduct small-scale experiments. The furnace well is suspended from the loor of the helium atmosphere glovebox shown in Fig. 4. Oxygen levels were maintained at $<4$ ppm and water at $<0.1 \mathrm{ppm}$ by a Vacuum Atmospheres Dri-Train purification system. The test cell was designed to fit in a standard-size furnace well commonly used in the Chemical Technology Division at Argonne National Laboratory. A stainless steel crucible was used to contain the electrolyte. This crucible was placed inside a $\mathrm{MgO}$ crucible to electrically isolate it from the furnace well that was at earth ground potential. These two crucibles were placed inside a third stainless steel crucible chat would catch the cell contents in the event of leakage or breakage of the crucibles. As shown in Fig. 3, the cell had two electrodes. One electrode was a metal rod (uranium, titanium or mild steel) attached to a stainless steel rod using a swagelock fitting. The other electrode was the sodium electrode and consisted of a sodium-filled $\beta$ "-alumina tube. The tube was supported by the assembly shown in Fig. 5. The assembly consisted of a stainless steel shroud with holes drilled in it. The $\beta$ "-alumina tube was placed in the shroud. The shroud was then joined to an alumina insulating tube with a swagelock connector. A steel rod was fed down through the alumina insulator, permitting electrical contact with the liquid sodium. An electrically isolated stainless steel stirrer was also placed in the salt phase. The cell temperature was monitored to within $\pm 0.2 \mathrm{~K}$ with a calibrated chromel$P^{\prime}$ imel thermocouple. Our standard teinperature of operation was $728 \mathrm{~K}$. Figure 6 shows ew of the top of the cell as seen through the glovebox window.

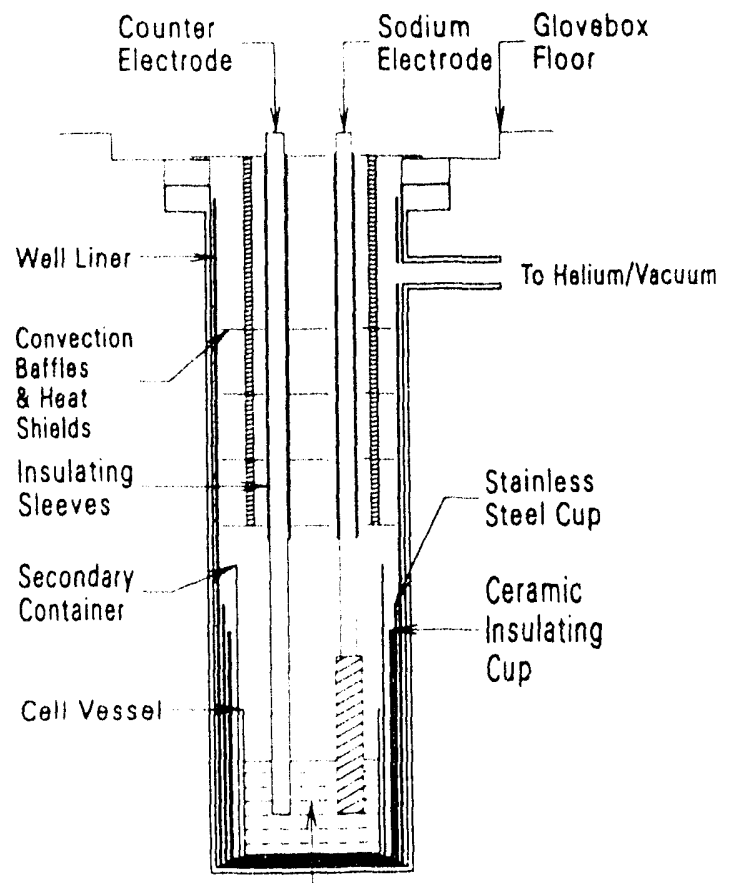

Fig. 3.

Diagram of Glovebox Furnace Well and Electrochemical Cell Used in all Experiments Described in this Report

Electrolyte 


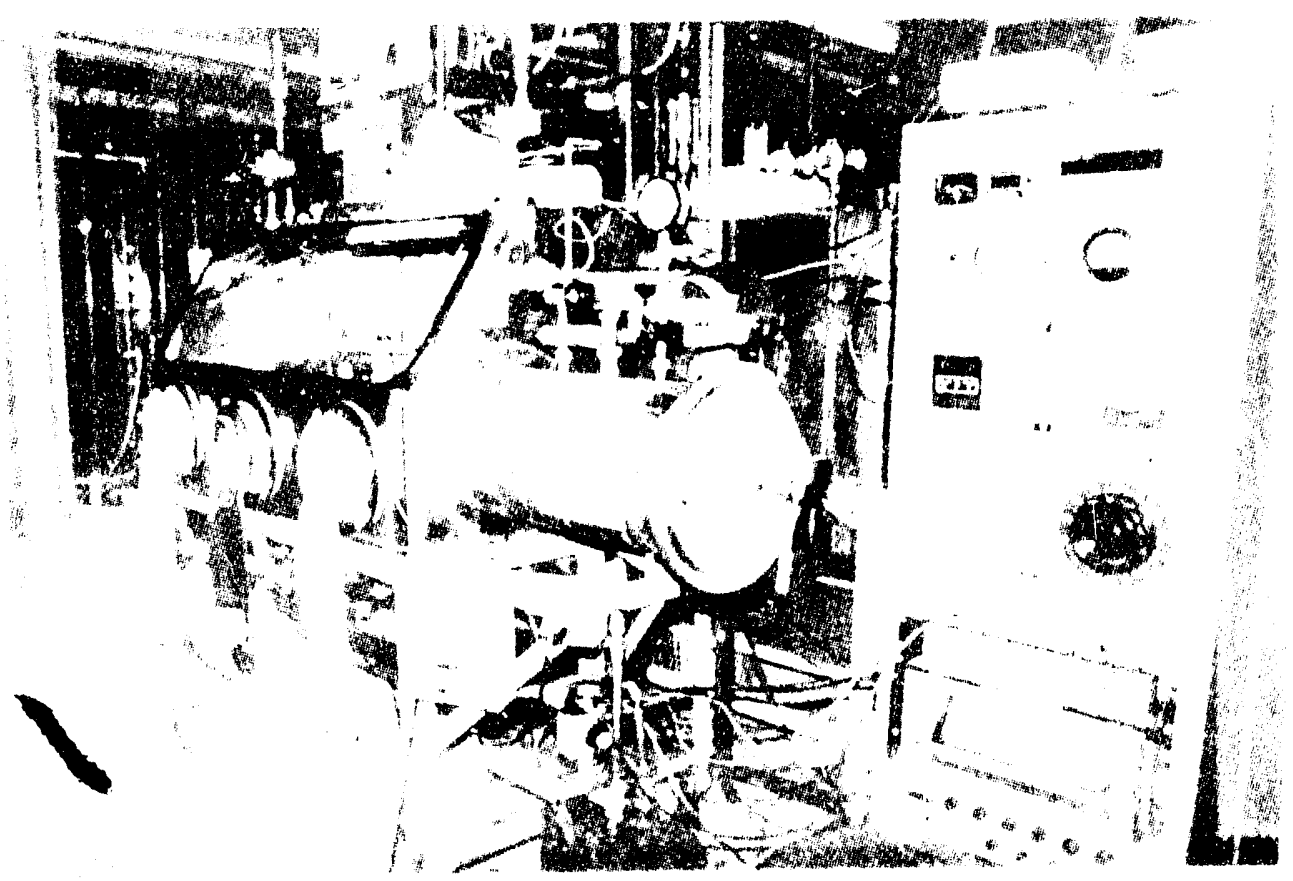

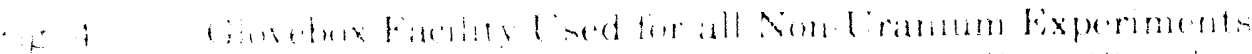

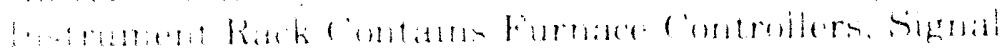

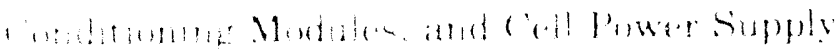

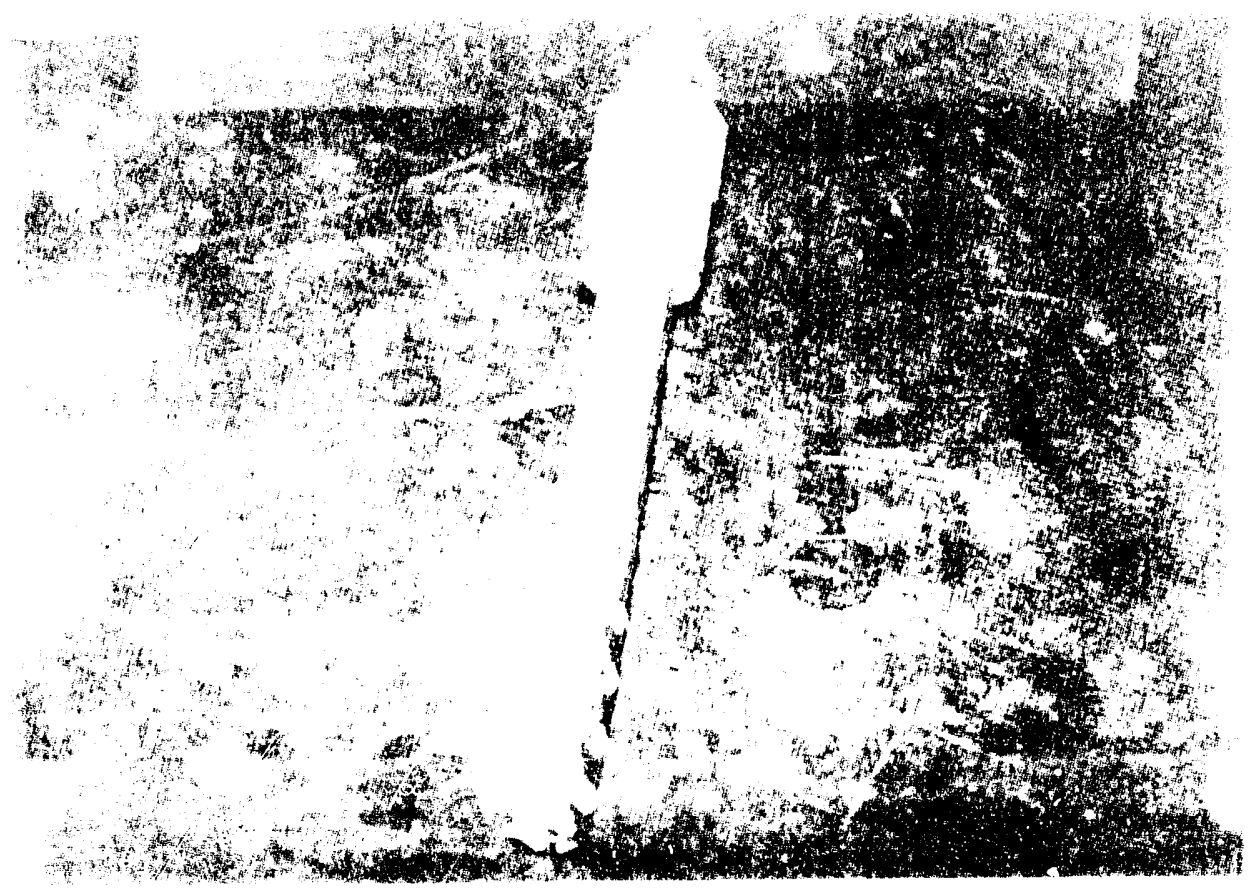

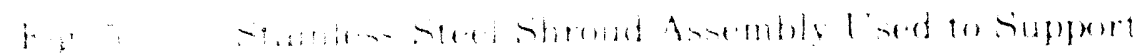




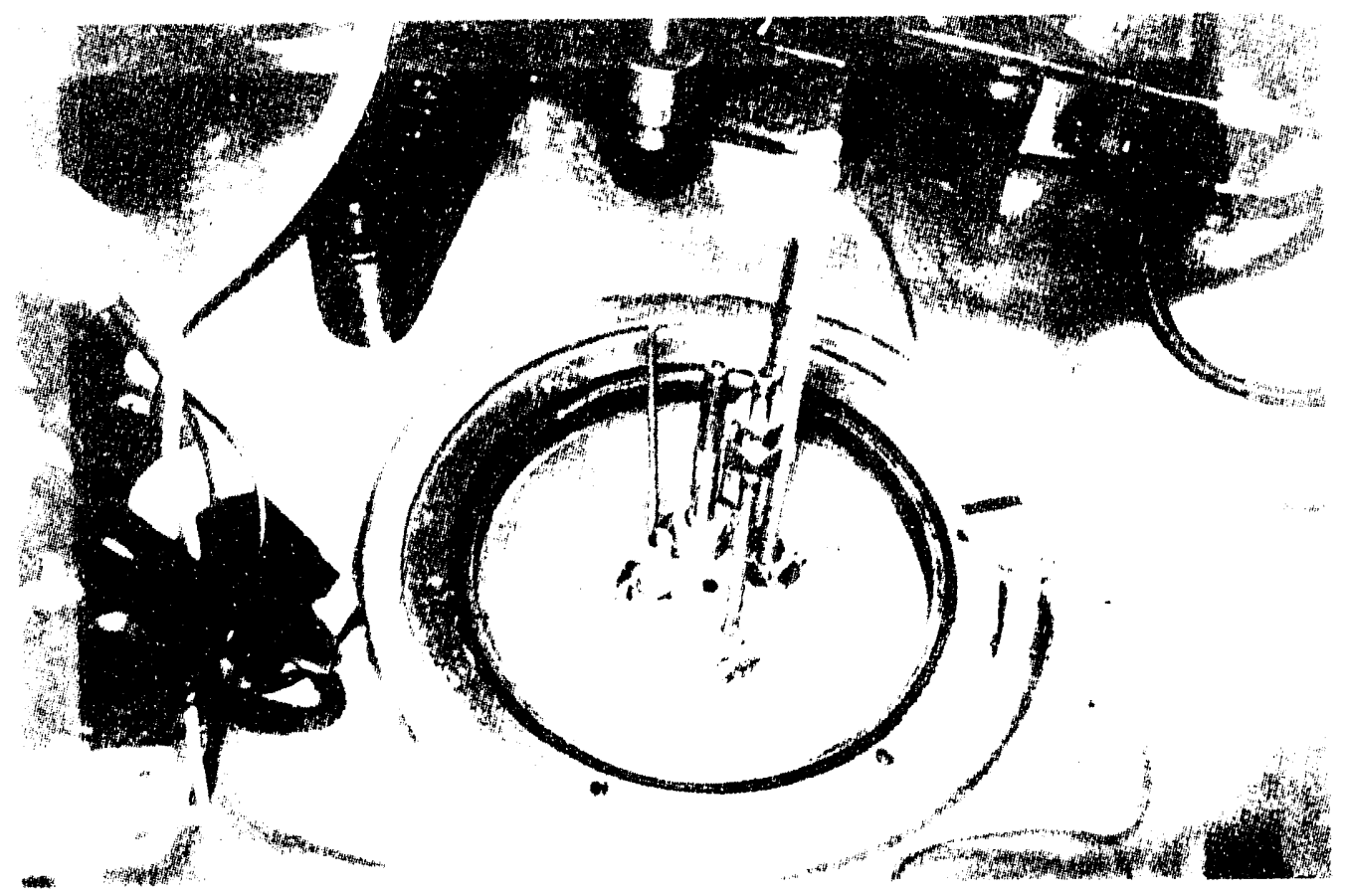

Hige ti Top View of Heat Shielde for Ion Replacement cell as Seen through the (ilovebox Windere Starting at the top and moving cleckwise items are sterrer. sodium ion replacement elentrede, themomele. and counter electrode.

Fexperiments were conducted at constant current and constant voltage An Edi\&e PAR Medel 173 potentiostat and a Fluke Medel $382 \mathrm{~s}$ voltage/current calibrator were used wantme the cell petental or current. Current, petental, and temperature data were

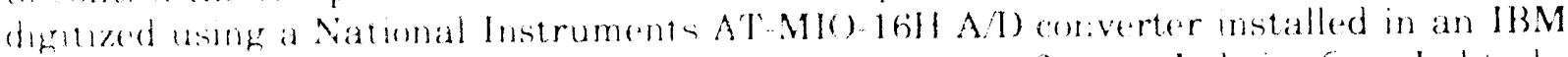
f' compatible computer. C'ommercial data acquisition software llabviewre or labtech Noteberke, was used to process and store the data for later analysis

\section{i. Expermeni:1 Pexedures}

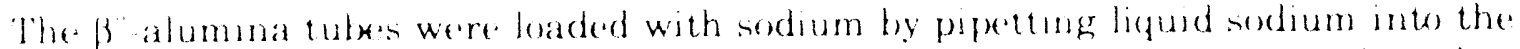
heated tute (Ince lodded the temperature was increased until the sodium wet the tube,

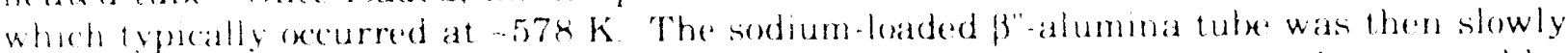
conled to rem temperature and placed in the holder. The entire cell was then assembled, lewered unte the fumace well. and heated at $2 \mathrm{~K} / \mathrm{min}$ to $72 \mathrm{~K}$ with the electrodes

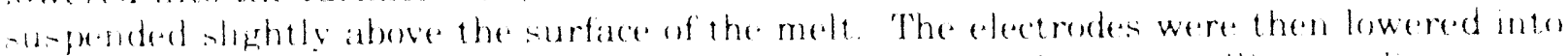
the melt, and the lead wires were conneeded to the electrodece using alligator clips

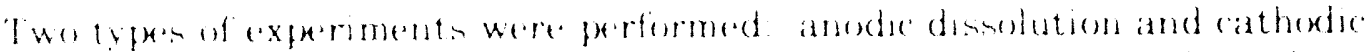

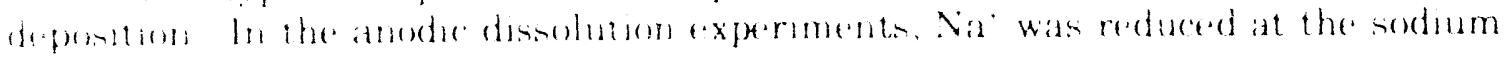


electrode and was replaced by $\mathrm{La}^{3+}, \mathrm{Dy}^{3+}, \mathrm{U}^{3+}$, or $\mathrm{Ti}^{\mathrm{n}+}$ formed by oxidation of the respective metais. In the cathodic deposition experiments, $\mathrm{La}^{3+}, \mathrm{Dy}^{3+}, \mathrm{U}^{3+}$, or $\mathrm{Ti}^{n+}$ ions were reduced at a mild steel cathode and were replaced by $\mathrm{Na}^{+}$ions formed by oxidation of sodium at the sodium anode. The molten salt was stirred to minimize concentration polarization. Cell currents typically ranged from 5 to $50 \mathrm{~mA}$. These currents correspond to current densities of 1 to $3 \mathrm{~mA} / \mathrm{cm}^{2}$ at the sodium ion replacement electrode and 20 to $65 \mathrm{~mA} / \mathrm{cm}^{2}$ at the counter electrode. Current densities were low due to low concentrations of $\mathrm{La}^{3+}$, $\mathrm{Dy}^{3+}, \mathrm{U}^{3+}$, or $\mathrm{Ti}^{\mathrm{n}+}$ in the electrolyte. Cell current, potential, total charge, and temperature data were acquired and stored every 60 seconds.

Filtered salt samples were taken using tantalum tubes fitted with a tantalum frit. The details of this procedure have been described previously. ${ }^{8}$ Inductively coupled plasma-atomic emission spectroscopy (ICP-AES) analyses of the molten salt and of cathode deposits were performed by the Analytical Chemistry Group of the Chemical Technology Division. The analytical results were reported to be accurate to $\pm 10 \%$.

\section{RESULTS AND DISCUSSION}

\section{A. Rare Earth Studies}

Dysprosium and lanthanum were chosen for the initial rare earth investigations because the separation between the $\Delta \mathrm{G}_{\mathrm{f}}^{\circ}$ values for $\mathrm{DyCl}_{3}$ and $\mathrm{LaCl}_{3}$ is $83 \mathrm{~kJ} / \mathrm{mol}$ or 0.286 $\mathrm{V}$ for a three-electron reaction. Referring to Table 1 , this degree of separation is sufficient to give a $>99.99 \%$ theoretical separation of the two metals by ion replacement if the potential is controlled. A comparable difference in $\Delta \mathrm{G}^{0}{ }_{\mathrm{f}}$ exists between $\mathrm{UCl}_{3}$ and $\mathrm{PuCl}_{3}$.

The initial study was performed using the cell shown in Fig. 3. In this experiment the potential was controlled. The anode was the sodium electrode, and the cathode was a $0.317-\mathrm{cm}$ dia mild steel rod. The anode and cathode reactions are as follows:

\section{Anode: $\quad \mathrm{Na} \rightarrow \mathrm{Na}^{+}+\mathrm{e}^{-}$}

$$
\text { Cathode: }\left[\begin{array}{l}
D y^{3}+3 e^{-}-D y \\
L a^{3}+3 e^{-}-L a
\end{array}\right]
$$

A plot of potential, current, and charge passed is shown in Fig. 7. The poiential was set initially at $1.0 \mathrm{~V}$, which gave a current of $0.8 \mathrm{~mA}$. The potential was decreased at $0.1 \mathrm{~V}$ increments then $0.05 \mathrm{~V}$ increments until the cell potential reached $0.05 \mathrm{~V}$. At this point the cell current was $16.8 \mathrm{~mA}$. The cell potential was then increased to $0.193 \mathrm{~V}$, at which point the cell current had decreased to essentially zero. The cell was left in this "parked" state overnight. The next day the cell potencial was decreased to $-0.035 \mathrm{~V}$. At this negative the following reaction should occur and cause a significant increase in cell current: 


$$
\text { Cathode: }\left[\begin{array}{c}
\mathrm{Na}^{+}+\mathrm{e}^{-} \rightarrow \mathrm{Na} \\
3 \mathrm{Na}+\mathrm{Dy}^{3} \rightarrow \mathrm{Na}^{+}+\mathrm{Dy} \\
3 \mathrm{Na}+\mathrm{La}^{3^{+}} \rightarrow \mathrm{Na}^{+}+\mathrm{La}
\end{array}\right]
$$

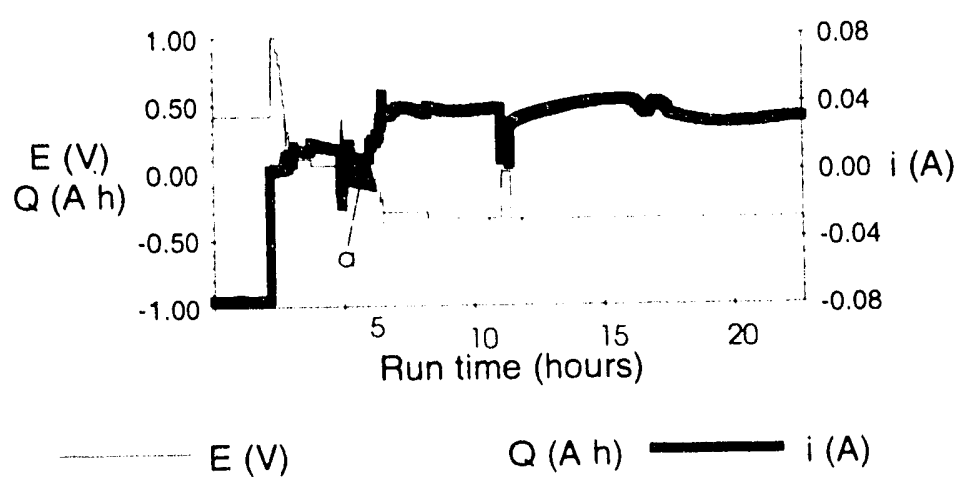

Fig. 7. Current (i), Potential (E), and Charge (Q) vs. Time for Experiment IRP-1

This increase in cell current is clearly evident in Fig. 7 at the point labeled "a". Although the cathode electrochemical reaction involves $\mathrm{Na}^{+}$, the net effect is that any $\mathrm{Dy}^{3+}$ or $\mathrm{La}^{3+}$ in the electrolyte would be reduced to dysprosium or lanthanum metals.

The total charge passed in this experiment was 0.075 equivalents. However, the calculated amount of charge required to deposit all the dysprosium and lanthanum from solution was much less, only 0.015 equivalents. Subsequent examination of the electrodes and heat shields after the experiment revealed a considerable amount of sodium metal in the cooler regions of the cell. The likely source of this sodium was sodium metal that had electrotransported from the ion replacement electrode to the cathode, where this sodium evaporated. The sodium vapor then condensed in the cooler regions of the cell. Thus, during the later part of the experiment, we must have been electrotransporting sodium from the ion replacement electrode to the cathode.

A photograph of the cathode deposit is shown in Fig. 8. This deposit appeared significantly less dendritic than we had expected based on our experience with uranium deposition from molten salts. The subsequent deposition of sodium on top of the lanthanum and dysprosium may be the cause of the smoother morphology. This observation will be investigated further in later experiments.

Results from the analysis of the cathode are given in Table 3. The metallic appearance of the deposit plus the high concentrations of dysprosium and lanthanum given in Table 3 indicates that we had successfully deposited $75 \%$ of the dysprosium and $64 \%$ of the lanthanum available from the electrolyte. The mass balance indicates that the 


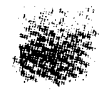

\section{की}

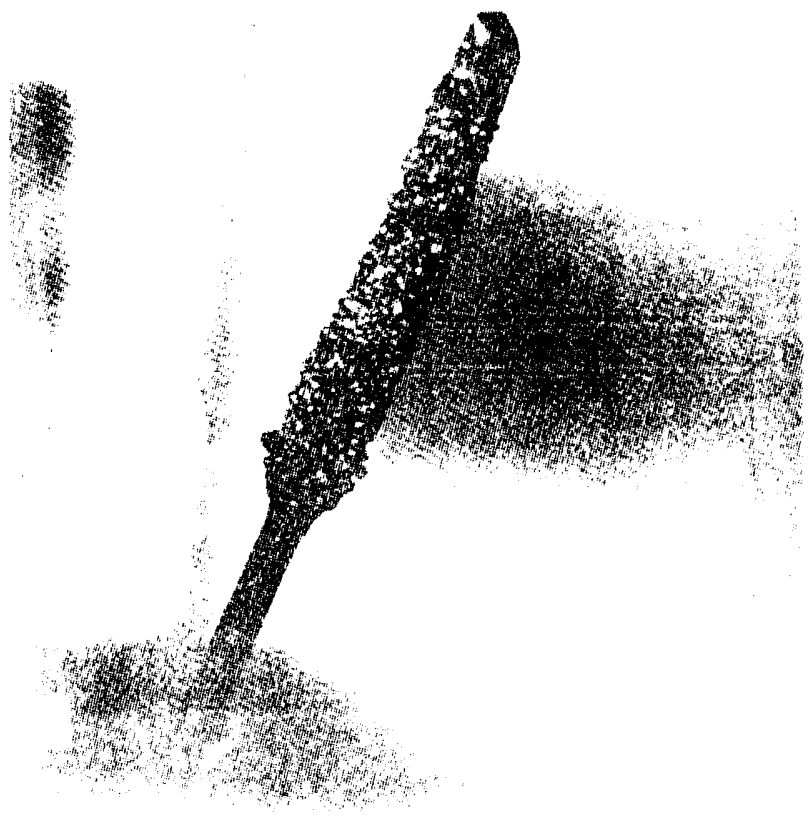

Fig. $x$.

Cathode Depesit from Experiment IRP.1

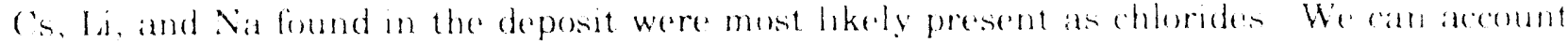
for $95 \%$ of the product mass if we assume that dysprosum and lanthanum deposited as metals and that the sodum, hathium, and cesium found on the deposit was due fordhesion or entrainment of the molten salt

Because the intent of the experiment was to completely deplete the salt of lat" and 1) $y^{\prime}$ " the apparent incemplete reduction was some what surprising We believe that loo";

Table :3 Analysis Results for Cathode Itepost from IRP.1. Bold type for numbers indicate probable form of species tmetal is chlorde salt). Total degresit mass was $2.350 \mathrm{gr}$

\begin{tabular}{|c|c|c|}
\hline Element & $\mathbf{w} \cdot \mathbf{t} \%$ & wt $\%$ as chloride. \\
\hline 1$) y$ & 16.3 & 270 \\
\hline la & 11.8 & $20 k$ \\
\hline $\mathrm{Na}$ & 258 & 6.6 \\
\hline 1,1 & 150 & 9.2 \\
\hline$\hookrightarrow s$ & 41 & 51.9 \\
\hline Total & 732 & 115,5619 \\
\hline
\end{tabular}


of the rare earths had been recovered from the electrolyte, but that some of the metal fell off the cathode. There was more than adequate time for dissolution to occur because the "final" sample was taken three weeks after the experiment was terminated. Thus, in this metal dissolution scenario, the dysprosium and lanthanum found in the salt at the end of the experiment was simply dissolved metal that had fallen off the deposit. Observations consistent with slight rare earth metal solubilities in molten salts ${ }^{9}$ add further credence to the metal dissolution scenario.

Table 4 gives the results of salt analysis at the beginning and at the end of the experiment. The level of dysprosium remaining in the salt accounts for the non-deposited dysprosium. If the metal dissolution scenario is indeed the source of soluble dysprosium and lanthanum, the final concentrations of dysprosium and lanthanum given in Table 4 are the first measurements of the solubility limit of those metals in the $\mathrm{CsCl}-\mathrm{LiCl}-\mathrm{NaCl}$ ternary salt at $728 \mathrm{~K}$.

Table 4. Initial and Final Concentration, Percent Change, and Change in Equivalents of $\mathrm{Dy}, \mathrm{La}$, and $\mathrm{Na}$ from Experiment IRP-1. Total salt mass was $326.31 \mathrm{~g}$.

\begin{tabular}{|c|c|c|c|c|}
\hline Species & $\begin{array}{c}\text { init. conc. } \\
(\text { wt\%) }\end{array}$ & $\begin{array}{c}\text { final conc. } \\
\text { (wt\%) }\end{array}$ & $\begin{array}{c}\% \text { change } \\
\text { in conc. }\end{array}$ & $\begin{array}{c}\Delta \text { eqiv. } \\
\mathbf{x} \mathbf{1 0}^{\mathbf{3}}\end{array}$ \\
\hline Dy & 0.156 & 0.018 & -89 & -8.32 \\
\hline La & 0.134 & 0.039 & -71 & -6.66 \\
\hline $\mathbf{N a}$ & 3.20 & 3.27 & +2.2 & 10 \\
\hline
\end{tabular}

The entire metal dissolution scenario will be explored again in Phase II by using a liquid tin cathode. Because dysprosium and lanthanum form strong intermetallic compounds with tin, their solubility in the molten salt should be decreased. With the results from these experiments, we will then be in a better position to determine whether metal dissolution is actually occurring.

To gain a better understanding of this system, we carried out thermodynamic calculations using SOLGAS, a computer program used to calculate equilibrium relationships in complex chemical systems. Originally developed by Eriksson, ${ }^{10}$ this program has been modified in order to run on an IBM compatible computer. The initial concentrations from experiment IRP-1 were fed into the program, and the results are displayed in Fig. 9 as a plot of moles of each species vs. cell potential. According to the SOLGAS calculation, $\mathrm{DyCl}_{3}$ will begirs to be reduced at about $0.75 \mathrm{~V}$ to $\mathrm{DyCl}_{2}$. At potentials $<0.67 \mathrm{~V}, \mathrm{DyCl}_{2}$ is reduced to metallic dysprosium. The solution will be assentially depleted of dysprosium ions at $0.55 \mathrm{~V}$. However, it is not until the potential reaches $0.45 \mathrm{~V}$ that $\mathrm{LaCl}_{3}$ will be reduced to metallic lanthanum, and at a potential of $0.25 \mathrm{~V}$, the solution should be essentially depleted of lanthanum ions. Thus, the SOLGAS calculation indicates that no $\mathrm{Dy}^{3+}$ or $\mathrm{La}^{3+}$ should be remaining in the electrolyte at the end of IRP-1. 


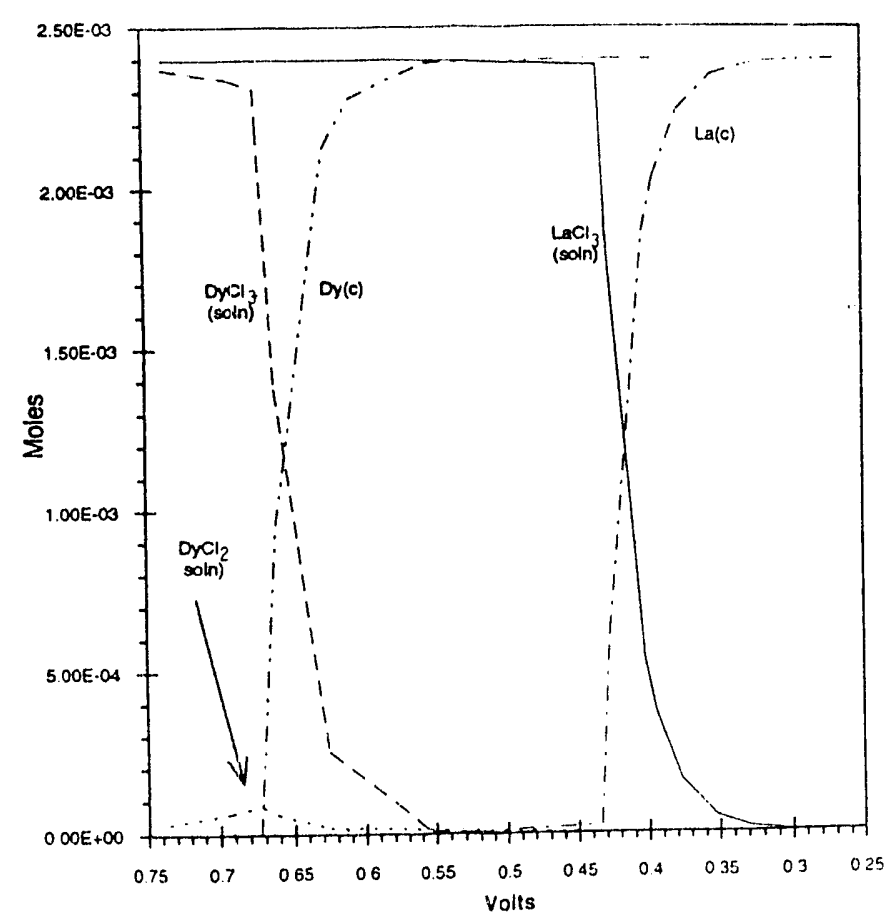

Fig. 9.

Plot of Concentration vs. Potential for $\mathrm{DyCl}_{3}, \mathrm{DyCl}_{2}, \mathrm{Dy}, \mathrm{LaCl}_{3}$, and La. Data are from SOLGAS calculation using same initial conditions as in experiment IRP-1.

Based on the results of the SOLGAS calculation, we decided to conduct the next experiment (IRP-2) under controlled-current conditions and to monitor the cell potential. The assumption was that, barring any significant kinetic or nucleation overpotentials, a comparison of the cell potential to the results of the SOLGAS calculation would indicate which species was being reduced. Conditions and concentrations identical to the initial experiment and to those used in the SOLGAS calculation were used, with the exception of controlled-current operation of the cell. Periodically the current was interrupted, and an open-circuit potential was measured. The total charge passed was carefully monitored, and the experiment was stopped after passing sufficient charge to deposit all of the dysprosium and $30 \%$ of the lanthanum.

The current, potential, and charge vs. time profiles for the next three experiments (IRP-2, IRP-3 and IRP-4) are shown in Fig. 10. Surprisingly, the two voltage plateaus indicative of dysprosium deposition and lanthanum deposition are not discernible in the IRP-2 portion of Fig. 10. From the SOLGAS calculation, we expected the potential vs. time trace to resemble a titration curve. One possible explanation of the failure to observe the expected two voltage plateaus is that the current was too high. For most of the experiment the cell current was set at $30 \mathrm{~mA}$. A rough calculation of the diffusionlimited current for dysprosium deposition indicated that it is of the same order of magnitude as the current used in IRP-2. Therefore, for the cell to sustain a $30 \mathrm{~mA}$ current, some reduction of $\mathrm{La}^{3+}$ occurred along with the reduction of dysprosium ions.

Although the current vs. time trace did not indicate a clear separation of dysprosium and lanthanum, the chemical analysis of the salt phase before and after the experiment indicated some degree of separation. These data are given in Table 5. A total charge of 0.048 equivalents was passed during the experiment. This agrees extremely well with the total decrease in equivalents of dysprosium and lanthanum reported in 


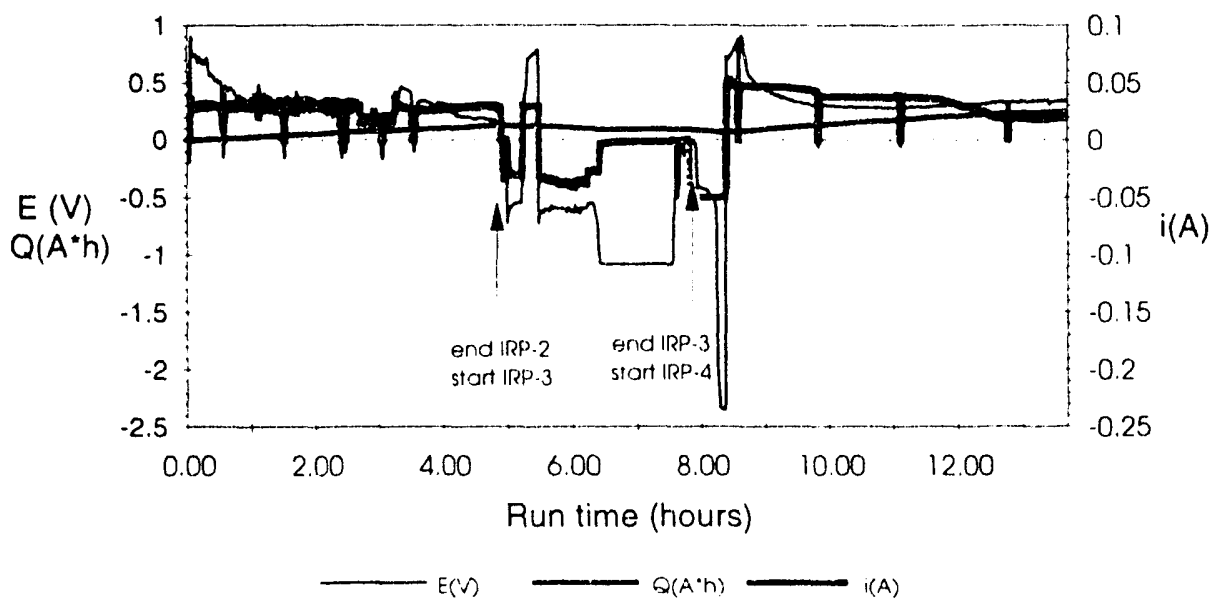

Fig. 10. Current, Potential, and Charge vs. Time Data from Experiments IRP-2, -3, and -4

Table 5 (0.049), indicating a coulombic efficiency of close to $100 \%$. The data in the fourth column show that our attempt at selective deposition was successful. We found a large decrease $(-77 \%)$ in the dysprosium concentration and only a small decrease $(-8.5 \%)$ in the lanthanum concentration.

The deposit from experiment IRP-2 was left in the cell for IRP-3. The polarity was then reversed to oxidize the deposit back into the molten salt and reduce $\mathrm{Na}^{+}$at the sodium electrode. However, after $1.2 \times 10^{-3}$ equivalents had been passed, there was a large downward shift in potential, as indicated in the IRP-3 portion of the potential vs. time trace in Fig. 10. This behavior suggested that the deposit had become dislodged from the electrode. A visual inspection of the electrode when it was removed confirmed that the deposit had fallen off.

After experiment IRP-3, we sampled the sodium inside the $\beta$ "-alumina tube, using the same procedure described earlier, and analyzed for lanthanum and dysprosium by ICP-AES. This analysis was done to determine if any lanthanum or dysprosium had

Table 5. Initial and Final Concentration, Percent Change, and Equivalents Charged or Discharged of Dy, La, and $\mathrm{Na}$ in Experiment IRP-2. Total Salt Mass was $200.0 \mathrm{~g}$.

\begin{tabular}{|c|c|c|c|c|}
\hline Element & $\begin{array}{c}\text { Init. Conc. } \\
(\mathbf{w t} \%)\end{array}$ & $\begin{array}{c}\text { Final Conc. } \\
\text { (wt\%) }\end{array}$ & $\%$ Change & $\begin{array}{c}\Delta \text { Equiv. } \\
\mathbf{x} \mathbf{1 0}^{3}\end{array}$ \\
\hline Dy & 0.156 & 0.036 & -77 & -4.4 \\
\hline La & 0.133 & 0.122 & -8.5 & -0.49 \\
\hline Na & 3.20 & 3.24 & +0.7 & 3.4 \\
\hline
\end{tabular}


exchanged through the $\beta$ "-alumina tube and possibly resulted in the potential shift observed in IRP-3. However, no trace of either rare earth was detected in the sodium. This analysis proved that rare earths were not electrochemically transported through the $\beta$ "-alumina and ruled out this phenomenon as a source of the potential shift observed in experiment IRP-3.

The deposition of dysprosium and lanthanum was continued in experiment IRP-4. Resulis of salt analysis before and after the experiment are given in Table 6 . The duration of this experiment was four hours, and the final salt sample was taken immediately after the current was turned off in order to minimize any confusion in the data caused by dissolution of the metal deposit. A total charge of $5.7 \times 10^{-3}$ equivalents was passed. From the change in concentration, the apparent current efficiency was $113 \%$. Furthermore, the dysprosium and lanthanum final concentrations of $0.004 \mathrm{wt} \%$ and 0.008 wt\%, repectively, indicate that deposition of these elements had nearly depleted the electrolyte of the rare earth chlorides, and that dissolution of the deposited metals had been minimized. Thus, either the rare earth metal dissolution rate in this electrolyte is extremely low or strong reducing conditions as found in IRP-1 are needed for metal dissolution to occur.

Table 6. Initial and Final Concentration, Percent Change, and Equivalents Charged or Discharged of Dy, La, and $\mathrm{Na}$ in Experiment IRP-4. Total salt mass was $200.0 \mathrm{~g}$.

\begin{tabular}{|c|c|c|c|c|}
\hline Element & $\begin{array}{c}\text { Init.Conc. } \\
\text { (wt\%) }\end{array}$ & $\begin{array}{c}\text { Final Conc. } \\
(\mathbf{w t} \%)\end{array}$ & $\%$ Change & $\begin{array}{c}\Delta \text { Equiv. } \\
\mathbf{x} \mathbf{1 0}^{\mathbf{3}}\end{array}$ \\
\hline Dy & 0.036 & 0.008 & -78 & -1.03 \\
\hline La & 0.17 & 0.004 & -98 & -7.17 \\
\hline Na & 3.71 & 3.88 & +4.58 & +14.8 \\
\hline
\end{tabular}

The dislodged deposit from IRP-3 that still remained in the cell was then chemically oxidized by the addition of $\mathrm{FeCl}_{2}$ in IRP-5. The potential between the sodium electrode and the cathode deposit from IRP-4 was monitored during the addition of the $\mathrm{FeCl}_{2}$. As expected, after the addition of $6.65 \times 10^{-3}$ equivalents $(0.844 \mathrm{~g})$ of the oxidant, the potential shifted in the positive direction and stabilized at $-1.72 \mathrm{~V}$. Current was passed briefly in each direction, and the cell responded as expected. Analysis of the salt after stabilization of the cell potential revealed that we had recovered $37 \%$ of the dysprosium and $72 \%$ of the lanthanum.

The purpose of the next experiment, IRP-6, was to examine the deposition of dysprosium and lanthanum by simply short circuiting the cell. Because the cathode vs. sodium electrode potential was positive, the reaction was expected to be spontaneous, analogous to discharging a battery. The current and potential vs. time traces are shown in Fig. 11. The initial current was $84 \mathrm{~mA}$ but quickly decayed to $\sim 30 \mathrm{~mA}$. The portions 


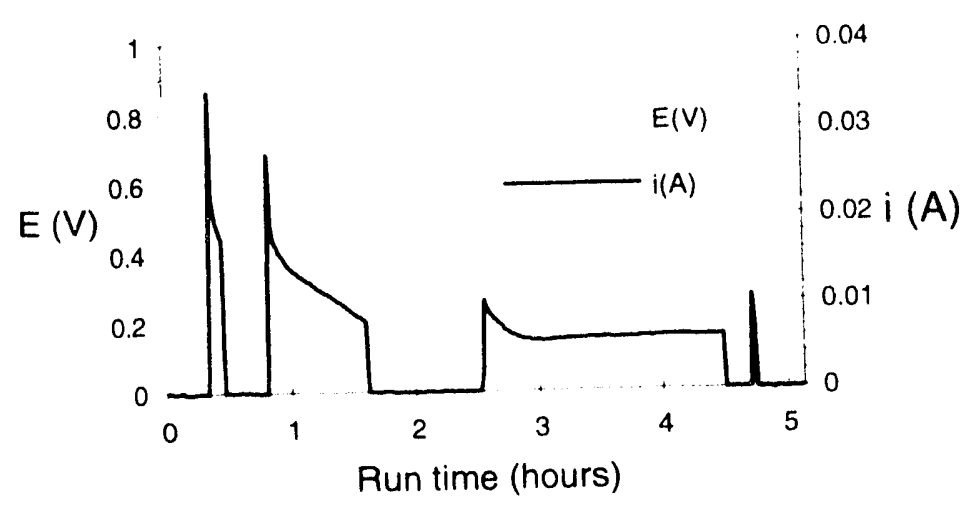

Fig. 11. Current, Potential, and Charge vs. Time Data from Experiment IRP-6. Zero current sections of potential data are open circuit measurements.

of Fig. 11 where the current is zero are open-circuit measurements. Once stabilized, the open-circuit measurements reflect the activities of $\mathrm{La}^{3+}$ and $\mathrm{Dy}^{3+}$ in the electrolyte.

After about 4.7 hours of operation, both the current and potential traces suddenly went to zero. The experiment was stopped, and the cathode rod was withdrawn to inspect the deposit. When the cathode rod was withdrawn, we found that the short section at the bottom had become disconnected at the swagelock union. The cathode rod was a twopiece design. A short rod at the bottom was connected to a longer rod by use of a swagelock connector. The bottom portion of the short rod was immersed in the electrolyte, and the longer rod extended up through the heat shields inside an alumina insulating tube. The cell temperature was then lowered to freeze the contents of the cell. Unfortunately, we had not passed sufficient current to detect any change in lanthanum and dysprosium concentrations. Additionally, severe scaling was observed on the outer surface of the $\beta^{\prime \prime}$-alumina tube. The scaling probably resulted from the exposure of the $\beta$ "-alumina to the $\mathrm{FeCl}_{2}$ in IRP-4. Nevertheless, the potential vs. time curve shown in Fig. 11 indicates that, as we predicted, the second step (deposition) in ion replacement electrorefining is spontaneous and can be achieved without any external voltage or current source.

Owing to the successful demonstration of the feasibility of the ion replacement concept with lanthanum and dysprosium, experiments IRP-7, $-9,-11$, and -13 were conducted to investigate the behavior of uranium.

\section{B. Uranium Studies}

The goals of the uranium studies (experiments IRP-7, $-9,-11$, and -13) were to demonstrate the ion replacement concept with a representative actinide (uranium) and to examine the compatibility of the $\beta$ "-alumina tube with respect to $U^{3+}$.

Because of stricter requirements involved with handling uranium, these experiments were carried out in a different glovebox from the one shown in Fig. 4 . This alternative glovebox had previously been approved for work with uranium and plutonium. 
An electrochemical cell identical to the one used in the rare earth studies was employed for these studies.

The counter electrode used in experiment IRP-7 was a $0.32-\mathrm{cm}$ dia uranium rod. The cell was configured so that the reactions at the anode and cathode were as follows:

Anode: $\quad U \rightarrow U^{3^{+}}+3 e^{-}$

Cathode: $\quad \mathrm{Na}^{+}+e^{-}-\mathrm{Na}$

After $1.0 \times 10^{-3}$ equivalents had passed, a steel rod was lowered into the molten salt. The salt that froze on the rod was pink, indicative of a $\mathrm{U}^{3+}$-containing salt. The salt was returned to the cell and not analyzed. No additional sample was taken. Physical examination of the uranium electrode indicated that the diameter had decreased, an observation consistent with the noted color change in the salt. The polarity was then reversed, and $1.0 \times 10^{-3}$ equivalents was passed to re-deposit the $\mathrm{U}^{3+}$ in the salt back onto the uranium rod. Four key observations led us to consider this experiment a success. First, small nodules of metal were observed on the uranium electrode. Second, the salt was essentially white when cool. Third, the uranium content was below the ICP-AES detection limit of $0.01 \mathrm{wt} \%$. Fourth, the salt was pink after the initial anodic dissolution step, indicating the presence of $\mathrm{UCl}_{3}$.

Encouraged by these initial findings, we repeated the experiment (IRP-9) and took a sample after the anodic dissolution step to verify uranium oxidation. The cell was configured to oxidize the uranium electrode and reduce $\mathrm{Na}^{+}$at the sodium electrode. After $0.9 \times 10^{-3}$ equivalents had passed, the salt was sampled. As observed in IRP-7, it was pink. Based on the assumption of $100 \%$ current efficiency, the salt was expected to have had a uranium concentration of $0.03 \mathrm{wt} \%$. Analysis of the salt by ICP-AES, however, indicated that the uranium concentration was $<0.01 \mathrm{wt} \%$, the detection limit for uranium. In IRP-7, this was the value found for white salt. Although the color change was a definite indication of uranium oxidation, the discrepancy between the expected and measured amounts of uranium in the salt suggested that other processes might be involved. One possible explanation for this discrepancy is that during this experiment some air was let into the glovebox. The oxygen then would have reacted with the $\mathrm{UCl}_{3}$ to form insoluble $\mathrm{UO}_{2}$, which would not show up in the filtered sample. To further investigate the apparent discrepancy, we decided to repeat the experiment.

In experiment IRP-11, the same uranium electrode was used, and the anode and cathode reactions were those given in Eqs. 4 and 5. This time, however, more charge was passed. After $1.6 \times 10^{-3}$ equivalents were passed, the uranium concentration in the molten salt should have been an easily detectable $0.053 \mathrm{wt} \%$. Qualitatively, the uranium concentration appeared to be higher since the sampled salt was a darker pink than in earlier experiments. The ICP-AES analysis of the sampled salt indicated a uranium concentration of $0.043 \mathrm{wt} \%$ and confirmed the qualitative visual observation. There was 
also a visible decrease in the diameter of the uranium rod as shown in Fig. 12. The obvious necking of the rod, along with the confirming uranium analysis of the salt, is clear evidence that we had oxidized uranium using the ion replacement approach.

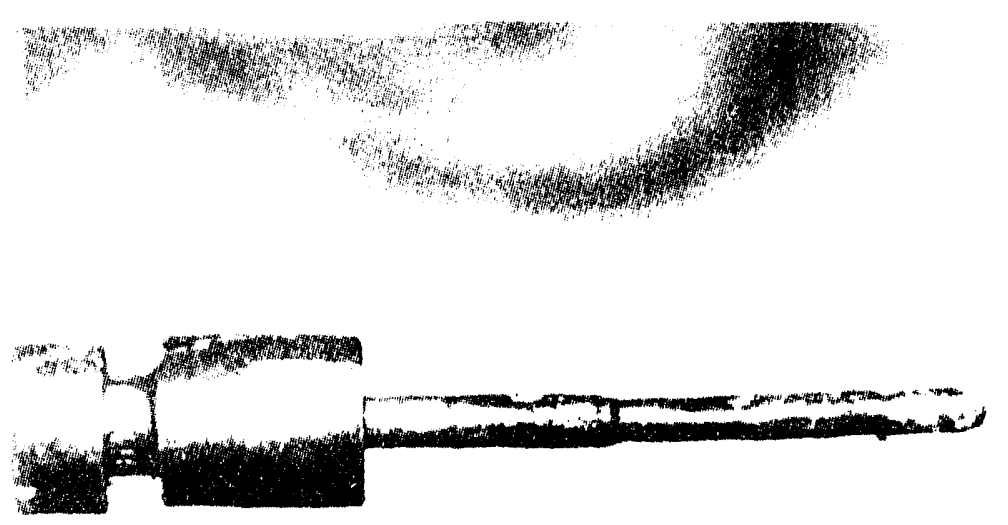

Fig. 12. Uranium Rod after Experiment IRP-11. Necking of rod due to uranium oxidation is clearly visible.

The purpose of the next experiment, IRP-13, was to obtain similar evidence of uranium reduction. In some respects, this experiment was a repeat of IRP-7 and IRP-9. However, a few modifications were made. First, $\mathrm{DyCl}_{3}$ was added to the cell so that separation of uranium and dysprosium could be examined. Second, after oxidation of the uranium electrode, the $\beta "$-alumina tube was left immersed in the $\mathrm{U}^{34}$-containing salt for one week in order to test its compatibility with $\mathrm{UCl}_{3 .}$ (Compatibility with $\mathrm{DyCl}_{33}$ and $\mathrm{LaCl}_{33}$ had already been demonstrated in experiments IRP-1 through IRP-6.) However, shortly after the re-deposition had started, the cell potential shifted to $<0.05 \mathrm{~V}$. The electrodes were withdrawn to a level slightly above the top of the salt, and the temperature was slowly lowered to freeze the contents of the cell. Examination of the cell revealed that the salt was white and the $\beta "$ "-alumina tube had ruptured. A dark layer had formed on the bottom of the salt ingot. 'The layer was presumably uranium metal that had been reduced by the sodium from the ruptured $\beta "$ "-alumina tube. We plan to microscopically examine the failed tube and determine the exact cause of its failure.

The rupture of the $\beta "$ "alumina tube observed in IRP-13 does not mean that this material cannot be used in processing uranium or dysprosium by ion replacement. I songterm stability is not an essential requirement of the sodium electrode. At a minimum, this electrode needs to remain intact and function for one oxidation or one deposition step. The tube that ruptured had remained intact through experiments $1 R P-7,-9$ and -11 . In those experiments, it did perform as expected. 
Additional compatibility studies of $\beta "$-alumina are planned. If these studies indicate a compatibility problem, we have already developed a strategy for protecting the $\beta "$-alumina tubes. In this strategy, a porous shroud is placed around the $\beta "$-alumina tube and filled with a more-compatible salt. Although some exchange of salt across the porous shroud may occur, the diffusion barrier should be adequate enough to provide short-term compatibility of the $\beta "$ "-alumina tube under harsher conditions.

Although the experiments described in this section have been preliminary, the results demonstrate that ion replacement electrorefining can be applied to the $\mathrm{U} / \mathrm{UCl}_{3}$ system. The actinide work conducted in Phase II will be aimed at addressing the $\mathrm{UCl}_{3} /$ $\beta^{\prime \prime}$-alumina compatibility issue and at demonstrating the ion replacement concept with actinides on a larger scale.

\section{Titanium Studies}

The objective of experiments IRP-8, -10 and -12 was a demonstration of ion replacement electrorefining with the $\mathrm{Ti}^{\mathrm{n}} / \mathrm{Ti}$ system. As this work was originally conceived, zirconium was to be the initial transition metal studied. For two rea: ions we decided to use titanium rather than zirconium for the initial investigations. Thi first reason was that the chemistry of titanium is quite similar to that of zirconium. 1. Iost notably, titanium has several stable oxidation states in a molten chloride electrolyte. The second reason was that titanium is also one of the small group of metals that is presently produced by a pyro-electrochemical process. ${ }^{1}$

Many of the transition metals pose an additional challenge to ion replacement electrorefining, since many of the transition metal chlorides are volatile or undergo disproportionation reactions. For instance, $\mathrm{TiCl}_{2}$ is expected to be somewhat soluble in the CsCl- $\mathrm{LiCl}-\mathrm{NaCl}$ salt, but $\mathrm{TiCl}_{3}$ and $\mathrm{TiCl}_{4}$ are expected to volatilize at our operating temperature of $728 \mathrm{~K}$. The redox potentials ( $\mathrm{vs}$. $\mathrm{Na}^{+} / \mathrm{Na}$ electrode) for the oxidation of titanium to $\mathrm{Ti}^{2+}, \mathrm{Ti}^{3+}$, and $\mathrm{Ti}^{4+}$ are approximately $-1.4 \mathrm{~V},-1.5 \mathrm{~V}$, and $-1.6 \mathrm{~V}$, respectively. Therefore, in our initial titanium oxidation experiment, IRP-8, the current was controlled so as to keep the cell potential between -1.45 and $-1.0 \mathrm{~V}$. However, analysis of the salt after passing $8.6 \times 10^{-3}$ equivalents showed that the titanium concentration was only 9 $\mathrm{ppm}$, a value considerably lower than the expected $0.1 \mathrm{wt} \%$. Visually, there was clear evidence of oxidation of the titanium rod. Based on the depth of rod immersion in the salt $(0.214 \mathrm{~cm})$, the measured rod diameter after the test $(0.615 \mathrm{~cm})$ and the original rod diameter $(0.635 \mathrm{~cm})$, we calculated that the mass loss should have been $0.191 \mathrm{~g}$. The calculated mass loss based on the total charge passed $\left(8.6 \times 10^{-3}\right.$ equivalents $)$ was $0.161 \mathrm{~g}$. The $0.030 \mathrm{~g}$ difference is well within the measurement error. The close correlation of mass loss with charge passed indicates that the electrochemical oxidation of titanium was occurring at close to $100 \%$ coulombic efficiency.

Two possible explanations account for the extremely low titanium concentration observed at the end of IRP-8: (1) $\mathrm{TiCl}_{2}$ formed but was extremely insoluble in the $\mathrm{CsCl}$ $\mathrm{LiCl}-\mathrm{NaCl}$ melt, and (2) $\mathrm{Ti}^{3+}$ or $\mathrm{Ti}^{4+}$ formed and volatilized out of the melt. Our IRP-8 data does not allow us to distinguish between these two possibilities.

To determine which was more likely, we repeated the experiment (IRP-10) with a more positive voltage limit of $-1.1 \mathrm{~V}$. In this test $5.1 \times 10^{3}$ equivalents was passed. If $\mathrm{Ti}^{2+}$ 
had been produced at $100 \%$ current efficiency, the solution concentration of titanium at the end of the test would have been $0.061 \mathrm{wt} \%$. The ICP-AES analysis shown in Table 5 yielded a iower value, $0.003 \mathrm{wt} \%$. Since the analysis was a factor of $\sim 20$ lower than expected, we inferred that again a loss of titanium had occurred.

Experimen IRP-12 was an attempt to identify the cause of this recurrent titanium loss. The cell polarity was reversed in order to re-deposit titaniurn. However, the cell current coul 1 not be increased above $1.5 \mathrm{~mA}$ without creating a negative cell potential, and the attempt at re-deposition was abandoned after passing $0.13 \times 10^{-3}$ equivalents of charge. After taking an additional filtered sample, we slowly decreased the furnace temperature to freeze the contents of the cell.

The filtered salt sample and a piece of the frozen salt were submitted for ICP-AES analysis. The results of these analyses are given in Table 6 . The analysis of the filtered sample $(0.003 \mathrm{wt} \% \mathrm{Ti})$ is consistent with the analysis of the sample taken after IRP-10. Furthermore, a comparison of the filtered and unfiltered results in Table 6 indicates that $\mathrm{TiCl}_{2}$ precipitated out of the molten salt. The concentration in the filtered sample may be the solubility limit of $\mathrm{TiCl}_{2}$ in this system.

Several cbservations were made in examining the ce!l after IRP-12. First, small black specks were scattered throughout the salt. Because the unfiltered sample was significantly higher in titanium than the filtered sample, the black specks are most likely precipitated $\mathrm{TiCl}_{2}$ or titanium metal. X-ray diffraction analysis of the precipitate phase will be conducted to help identify the material. Second, a thin black layer of material appeared on the bottom of the cell crucible. This material is also most likely $\mathrm{TiCl}_{2}$ or titanium metal. Third, a fine black deposit was found on the crucible walls in a $\sim 1 \mathrm{~cm}$ wide band just above the salt level. A preliminary analysis of this deposit indicates that it is composed primarily of the $\mathrm{CsCl}-\mathrm{LiCl}-\mathrm{NaCl}$ ternary salt but also contains $6.8 \mathrm{wt} \%$ titanium. The source of the deposit is uncertain. One possible source is $\mathrm{TiCl}_{4}$ or $\mathrm{TiCl}_{3}$ that volatilized and condensed on the crucible walls. Alternatively, the deposit could have formed due to splashing of the molten salt up on the crucible walls during stirring. The latter source seems more likely because the deposit was found only on the walls of the crucible and not in any of the cooler regions of the cell. Again, X-ray diffraction analysis of the deposited material will be conducted to help identify this material and discern between the two possible sources for its origin.

In spite of various experimental difficulties, these experiments demonstrated that the ion replacement approach can be used to oxidize titanium metal. Furthermore, the formation of a volatile species may actually be advantageous in certain circumstances, such as the separation of titanium from other metals that do not form a volatile oxidized species.

\section{CONCLUSIONS}

In conclusion, the feasibility of ion replacement electrorefining has been successfully demonstrated by the work conducted in Phase I, and the program is proceeding on schedule. The Phase I goals described in Sect. I.B were achieved in experiments IRP-1 through IPR-13. Using a sodium ion replacement electrode, anodic 
dissolution and cathodic deposition of rare earth and actinide metals were demonstrated. Rare earth chloride concentrations in the electrolyte were decreased to $<0.008 \mathrm{wt} \%$. Oxidation of a transition metal, titanium, was also demonstrated. Adequate short-term compatibility between the $\beta$ "-alumina tube and the molten salt electrolyte was observed. Long-term stability may prove difficult to attain but is not critical to the development of this technology. Lastly, a suitable alternative to the sodium ion replacement electrode has been identified. The alternative, a $\mathrm{Li} / \mathrm{Sb}$ alloy electrode, is discussed further in the next section of this report.

\section{FUTURE WORK}

In Phase II we will design and construct a laboratory-scale (500 g) electrorefiner for further development of ion replacement electrorefining. Development of the sodium ion replacement electrode will continue on several fronts. The development of a porous shroud for enhanced compatibility of the $\beta^{\prime \prime}$-alumina tube will also be investigated in the laboratory-scale ion replacement electrorefiner. We will also examine the compatibility between $\beta "$-alumina and the $\mathrm{LiCl}-\mathrm{KCl}$ eutectic salt that is used in several pyroelectrochemical processes. Of particular interest is the exchange of potassium for sodium ions and the effect of this exchange on the strength and ionic conductivity of the $\beta$ "alumina. In addition we plan to develop some diagnostic tools for assessing changes in the performance of the $\beta "$-alumina tube. Both dc resistance measurements and ac impedance measurements will be investigated as tools for measuring changes in the sodium ion conductivity of $\beta "$-alumina.

In addition to further development of the sodium electrode, we will begin to pursue the concept of an alloy-based ion replacement electrode. Allcy-based electrodes have two possible applications. In one application, the activity of deposited metals, such as dysprosium and lanthanum, can be decreased by depositing these metals into liquid tin, thus 'owering their solubility in the molten salt. These experiments should also provide more accurats data on the activity coefficients of lanthanum, dysprosium, and other rarr earth metals in the $\mathrm{CsCl}-\mathrm{LiCl}-\mathrm{NaCl}$ salt. In the second application, alloy electrodes can be used as an alternative to the sodium ion replacement electrode. In our initial work we will use a $\mathrm{Li}_{3} \mathrm{Sb}$ alloy. The activity of lithium can be lowered sufficiently so as to shift the lithium redox potential $\sim 0.7 \mathrm{~V}$ by the formation of the intermetallic compound. ${ }^{12}$ Our calculations predict that this alloy will be stable with respect to the rare earth metals and plutonium. The use of this alloy electrode for reduction of rare earth chlorides and $\mathrm{PuCl}_{3}$ will be pursued in Phase II.

Finally, as the work in Phase II progresses, we will seek continued funding of this technology with outside sources. We feel that there is a strong possibility of continued support from industrial and federal sponsors, such as Lithcoa and Los Alamos National Laboratory

\section{ACKNOWLEDGMENTS}

This work is being funded by the United States Department of Energy, Office of Basic Energy Sciences, Division of Advanced Energy Projects. 


\section{REFERENCES}

1. J. I. Willit, W. E. Miller, and J. E.Battles, "Electrorefining of uranium and plutonium--A literature review," J. Nucl. Mat., 195, 229-249 (1992).

2. L. Burris, R. K. Steunenberg, and W. E. Miller, "The application of electrorefining for recovery and purification of fuel discharged from the integral fast reactor," in Electrochemical Engineering Applications, R. E. White, R. F. Savinell, and A. Schneider, Eds., AlChE, New York, Vol. 254, pp. 135-142 (1987).

3. J. H. Kennedy, "The B-aluminas," in Solid Electrolytes, S. Geller, Ed., Springer-Verlag, New York, Vol. 21, pp. 105-141 (1977).

4. B. B. Owens and P. M. Skarstad, "Ambient temperature solid state batteries," in Fast Ionic Transport in Solids--Electrodes and Electrolytes, P. Vashishta, J. N. Mundy, and G. K. Shenэy, Eds., North-Holland, New York, pp. 61-67 (1979).

5. S. Basu and W. Worrell, "Chemical diffusivity of lithium in $\mathrm{Li}_{\mathrm{x}} \mathrm{TaS}_{2}$ and $\mathrm{Li}_{x}{ }_{\mathrm{x}} \mathrm{TiS}_{2}$," in Fast Ionic Transport in Solids--Electrodes and Electrolytes, P. Vashishta, J. N. Mundy, and G. K. Shenoy, Eds., North-Holland, New York, pp. 149-152 (1979).

6. I. S. Morozov and B.G. Korshunov, "Investigation of the interaction of thorium chloride with chlorides of alkali metals," Izv. Vysshikh. Ucheb. Azvedenni Tsvetnaya Met., $\underline{3}$ (3), 102 (1960).

7. R. J. Borg and G. J Dienes, The Physical Chemistry of Solids, Academic Press, New York, pp. 174-176 (1992).

8. D. S. Poa, Z. Tomczuk, and R. K. Steunenberg, "Voltammetry of uranium and piuconium in molten $\mathrm{LiCl}-\mathrm{NaCl}-\mathrm{CaCl}_{2}-\mathrm{BaCl}_{2}$ : I. Reduction of U(III) to urarium metal,"J. Electrochem. Soc., 135, 1161-1166 (1988).

9. John Ackerman, Argonne National Laborate:y, private communication, 1993.

10. G. Ericksson, Acta. Chem. Scand., 25, 2651 (1971).

11. G. Cobel, J. Fisher, and L. is. Snyder, "Elertrowinning or titanium from titanium tetrachloride: Pilot plant experience and production plant predictions," in Titanium '80: Science and Technology: Proceedings of the Fourth International Conference in Titanium, H. Kimura and O. Izumi, Eds., Metallurgical Society of AIME, Warrendale, PA, pp. 1969-1976 (1980). 
12. R. A. Huggins, "Evaluation of properties related to the application of fast ionic transport in solid electrolytes and mixed conductors," in Fast Ionic Transport in Solids--Electrodes and Electrolytes, P. Vashishta, J. N. Mundy, and G. K. Shenoy, Eds., North-Holland, New York, pp. 53-59 (1979). 
Distribution for ANL-93/24

Internal:

J. P. Ackerman

D. L. Barney

J. E. Battles

R. L. Breyne

L. Burris

Y. C. Chang

A. K. Fischer

E. C. Gay

J. E. Harmon

1. Johnson
T. R. Johnson

J. J. Laidler

V. A. Maroni

W. E. Miller

K. M. Myles

M. J. Steindler

C. E. Till

Z. Tomczuk (10)

J. L. Willit (10)

TIS Files

\section{External:}

DOE-OSTI, for distribution per UC-401 (48)

ANL-E Library (2)

ANL-W Library

Manager, Chicago Operations Office, DOE

Chemical Technology Division Review Committee Members:

S. Baron, Brookhaven National Laboratory, Upton, NY

D. L. Douglas, Consultant, Bloomington, $\mathrm{MN}$

N. Jarrett, Noel Jarrett Associates, Lower Burrell, PA

J. G. Kay, Drexel University, Philadelphia, PA

J. Stringer, Electric Power Research Institute, Palo Alto, CA

J. B. Wagner, Arizona State University, Tempe, AZ

R. G. Wymer, Consultant, Oak Ridge, TN

D. Bowersox, Los Alamos National Laboratory, Los Alamos, NM

W. M. Polansky, USDOE, Office of Basic Energy Sciences, Germantown, MD 

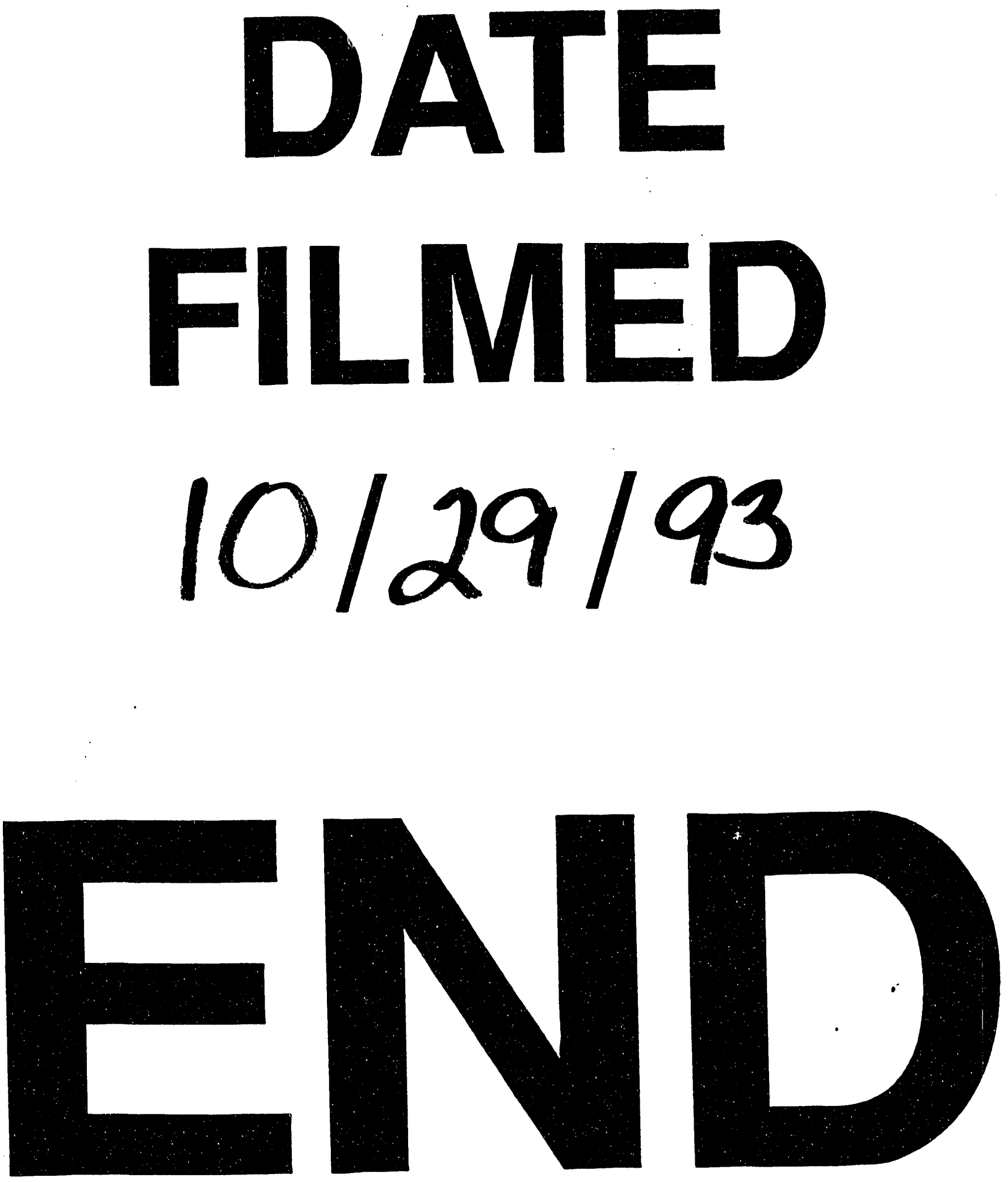
$\ldots$ 